Institute of $\mathbf{F}_{\text {ood and }} \mathbf{A}_{\text {gricultural }} \mathbf{S}_{\text {ciences }}$

\title{
Florida Solid and Hazardous Waste Regulation Handbook: Federal Agencies ${ }^{1}$
}

\section{Michael T. Olexa, Aaron Leviten, and Kelly Samek ${ }^{2}$}

There are four federal agencies that regulate solid and hazardous waste:

1. The Environmental Protection Agency (EPA)

2. The United States Coast Guard (USCG)

3. The Army Corps of Engineers (ACOE)

4. The Department of Transportation (DOT)

\section{What Does the Environmental Protection Agency (EPA) Do?}

The Environmental Protection Agency (EPA) was established as an independent agency in the executive branch of the U.S. government in 1970. EPA was created to regulate all aspects of the environment, especially the pollution of natural resources. EPA is empowered to fulfill its purpose through many laws. These laws include RCRA (regulating the disposal of solid and hazardous waste), CERCLA (providing for the cleanup of sites that pose a threat to human health and the environment), FIFRA (regulating the use and disposal or pesticides), EPCRA (regulating planning for spills), the ODA (regulating disposal into U.S. oceans and territorial waters), the CAA (regulating release of pollutants into the atmosphere), and the CWA (regulating disposal into U.S. water bodies).

EPA has 10 regional offices located throughout the United States. Florida falls within the jurisdiction of the Region 4 office, headquartered in Atlanta, Georgia. You may wish to contact this office about permitting for disposal of waste into the ocean and other bodies of water; use, application, and disposal of pesticides; or the disposal of hazardous wastes. (Contact the Atlanta office for reporting spills at 404-562-8700 and for cleanup information at 1-800-564-7577).

\section{What Does the United States Coast Guard (USCG) Do?}

In concert with EPA, the Coast Guard is responsible for enforcing the Ocean Dumping Act and the Clean Water Act. Anyone found in violation of these statutes by the Coast Guard may be subject to severe penalties.

1. This is EDIS document FE453, a publication of the Department of Food and Resource Economics, Florida Cooperative Extension Service, UF/IFAS, University of Florida, Gainesville, FL. Published December 2003. Please visit the EDIS website at http://edis.ifas.ufl.edu.

2. Michael T. Olexa, Professor in the Department of Food and Resource Economics and Director of the Agricultural Law Center, Florida Cooperative Extension Service, UF/IFAS, University of Florida, Gainesville, FL, and Member of the Florida Bar and Chair of the Agricultural Law Committee of the Florida Bar; Aaron Leviten, Attorney in Orlando and guest lecturer on pesticide litigation at the University of Florida; and Kelly Samek, 2003 graduate of the Levin College of Law at the University of Florida.

The Institute of Food and Agricultural Sciences is an equal opportunity/affirmative action employer authorized to provide research, educational information and other services only to individuals and institutions that function without regard to race, color, sex, age, handicap, or national origin. For information on obtaining other extension publications, contact your county Cooperative Extension Service office. Florida Cooperative Extension Service/Institute of Food and Agricultural Sciences/University of Florida/Christine Taylor Waddill, Dean. 


\section{What Does the Army Corps of Engineers (ACOE) Do?}

The Army Corps of Engineers is responsible for dredge-and-fill permitting pursuant to the Clean Water Act. EPA has the authority to veto any permit. The Corps is primarily responsible to the Secretary of the Army.

\section{What Does the Department of Transportation (DOT) Do?}

The Department of Transportation (DOT) regulates all aspects of transportation, including the transportation of hazardous wastes and materials. Non-compliance with DOT regulations can result in severe penalties. DOT and EPA work together to develop laws regulating the transportation of hazardous wastes. As a result, the rules of the two agencies often refer to each other. Violating the regulations of either agency may subject you to penalties from both.

\section{Acknowledgments}

The authors are indebted to the personnel of both state and federal agencies who gave their time and advice in the preparation of this handbook. The authors are also indebted to the following University of Florida personnel for a review and critique of the first draft of this publication: Dr. Thomas Dean, Pesticide Education Specialist, and Dr. Norman Nesheim, Pesticide Information Coordinator. Special recognition is also due to Mr. Richard Budell of the Office of Agricultural Water Policy of the Florida Department of Agriculture and Consumer Services for providing funds for the development of this handbook.

This handbook is designed to provide an accurate, current, and authoritative summary of the principal Florida laws that directly or indirectly relate to agriculture. It should provide a basic overview of the many rights and responsibilities farmers and farmland owners have under Florida laws. The reader is provided information about these rights and responsibilities and the appropriate contacts for more detailed information. However, the reader should be aware that because the laws, administrative rulings, and court decisions on which this publication is based are subject to constant revision, portions of this publication could become outdated at any time. Many details of cited laws are also left out due to space limitations.

This handbook is distributed with the understanding that the authors are not engaged in rendering legal or other professional advice and the information contained herein should not be regarded or relied upon as a substitute for professional advice. It is not all-inclusive in providing information to achieve compliance with laws and regulations governing the practice of agriculture. For these reasons, the use of these materials by any person constitutes an agreement to hold harmless the authors, UF/IFAS, the Agricultural Law Center, and the University of Florida for any liability claims, damages, or expenses that may be incurred by any person as a result of reference to or reliance upon the information contained in this publication. 